\title{
Longevity of Epidendrum ibaguense Inflorescences Influenced by the Storage Temperature and Ethylene Inhibitor
}

\author{
Joice Simone dos Santos ${ }^{1}$, Fernando Luiz Finger ${ }^{2 *}$, Ana Maria Mapeli ${ }^{3}$, Juliane Karsten ${ }^{1}$, \\ Teresa Drummond Correia Mendes ${ }^{1}$ and José Geraldo Barbosa ${ }^{2}$ \\ ${ }^{I}$ Departamento de Fisiologia Vegetal; Universidade Federal de Viçosa; C.P. 36570-000; Viçosa - MG - Brasil. \\ ${ }^{2}$ Departamento de Fitotecnia; Universidade Federal de Viçosa; C.P. 36570-000; Viçosa - MG - Brasil. ${ }^{3}$ Instituto de \\ Ciências Ambientais e Desenvolvimento Sustentável; Universidade Federal da Bahia; C.P. 47805-100; Barreiras - \\ BA - Brasil
}

\begin{abstract}
This work had the goal to evaluate the influence of temperature and dry storage on the postharvest longevity of Epidendrum ibaguense flowers previously treated with silver thiosulfate (STS). The flowers were harvested and pulsed for 30 minutes with $2 \mathrm{mM}$ STS. Then both, the STS treated and untreated flowers were packed in perforated low density polyethylene bags, packed in cardboard boxes and stored at 5 and $10^{\circ} \mathrm{C}$, where they remained for four and eight days. After this period, the flowers were kept in vase with distilled water at $25^{\circ} \mathrm{C}$, and analyzed at every 24 $h$. The experiment was arranged in a complete random design $2 \times 2 \times 2$ factorial scheme, with four replicates, containing four inflorescences each, except for the determination of transpiration and water rates uptake, composed by sixteen replicates of one stem. The vase life of the flowers of the E. ibaguense was increased to 6.5 days when pulsed with $2 \mathrm{mM}$ STS for 30 minutes, followed by storage at $10^{\circ} \mathrm{C}$ for a maximum period of four days. The STS applied before the cold storage reduced the rate of flower abscission and improved the ratio between the transpiration and water uptake.
\end{abstract}

Key words: orchid, cut flower, temperature, abscission

\section{INTRODUCTION}

The Orchidaceae family comprises a large proportion of the all the families of flowering plants, with an estimated 25,000 - 30,000 species worldwide (Pridgeon 2003). The commercial sales for the cut flowers in Brazil experienced a fast increase in the past decade, mainly due to more sales in the internal market, but the interest for new products abroad is enormous. The tropical ground orchid Epidendrum ibaguense is an excellent example of a new cut flower that can be introduced in the local and international markets, because of its relatively extended vase life (Moraes et al. 2009). However, for a successful commercialization as cut flower, a proper care must be taken regarding the postharvest handling during the shipping, wholesale and retail stores.

Several factors reduce the vase life of cut flowers, among them the reduced capacity of water uptake and changes associated with ethylene production and sensitivity are the main causes for the wilting and abscission of the flowers (Finger and Barbosa 2006). The reduction on water status can be

*Author for correspondence: ffinger@ufv.br 
relieved or restored by cutting the base of the stem and by placing the flowers in proper vase solutions (Suzuki et al. 2001). Usually, the presence of substances that increase the water viscosity in the vase solution impair the capacity of water uptake. Thus, as a general role, it is recommended to use the hydration solutions in the form of pulsing, followed by immediate transfer to water (Van Doorn 1997).

Ethylene enhances the senescence in the flowers in response to the stresses as well as autocatalytic production in climacteric flowers such as carnation and orchids (Verlinden et al. 2002; Mapeli et al. 2009). A previous study has shown that $E$. ibaguense flowers are sensitive to ethylene, showing intense wilting and abscission after being exposed to relatively low concentrations (Moraes et al. 2007). Therefore, the use of 1methylcyclopropene or silver-containing solutions is necessary to enhance the vase life of cut $E$. ibaguense flowers (Finger et al. 2008).

During the postharvest storage of flowers, the high rates of respiration and water loss accelerate the senescence. Thus, cold storage diminishes the rate of senescence, but the low temperature can induce the chilling injury symptoms in most of the tropical and subtropical flowers (Finger and Barbosa 2006). Flowers such as bird-of-paradise alpinia and heliconia develop chilling symptoms when stored between 10 to $13^{\circ} \mathrm{C}$ (Finger et al. 2003; Jaroenkit and Paull 2003). The symptoms usually intensify when the product is transferred from the cold storage to room temperature (Morris 1982). For the E. ibaguense flowers, there is no information regarding the sensitivity of this species to chilling and what kind of symptoms may develop during the cold storage. Thus, the aim of this work was to evaluate the effect of temperature and length of the storage on vase life of E. ibaguense flower pulsed or not with silver thiosulphate.

\section{MATERIALS AND METHODS}

Inflorescences stalks of E. ibaguense were harvested in the morning $(8 \mathrm{a} . \mathrm{m}$.) at stage number 10 of development (Fig. 1), corresponding at least to 20 open flowers as established by Moraes et al. (2007).

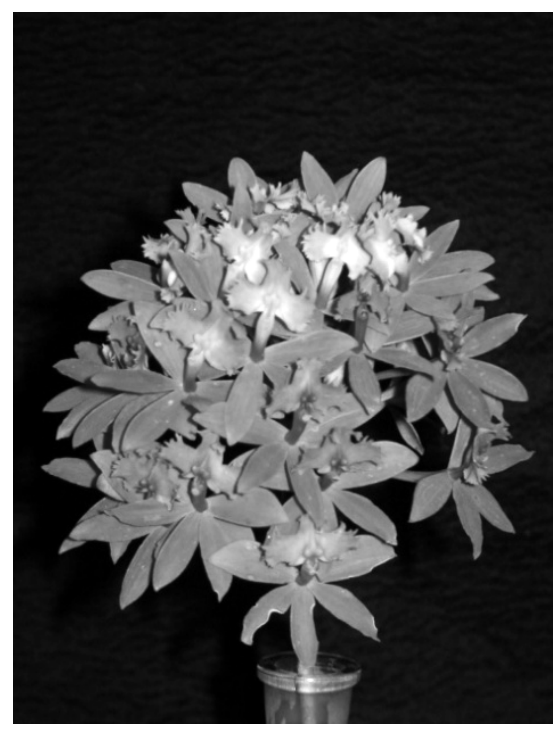

Figure 1 - Commercial harvest stage of E. ibaguense inflorescence.

After the harvest, the inflorescences were placed in the buckets with distilled water and the base of stalk was re-cut to $30 \mathrm{~cm}$ long. Afterwards, the inflorescences were pulsed with $2 \mathrm{mM}$ silver thiosulphate (STS) for 30 minutes or placed in distilled water (control) for the same period of time. In order to simulate the shipping, the inflorescences were wrapped in low density polyethylene bags $(40 \mathrm{~cm}$ length $\times 20 \mathrm{~cm}$ wide) containing 32 perforation of $0.5 \mathrm{~cm}$ in diameter and placed in closed cardboard boxes $(45 \mathrm{~cm}$ long $\times 20 \mathrm{~cm}$ wide $\times 15 \mathrm{~cm}$ height), lying down horizontally and immediately placed at 5 and $10^{\circ} \mathrm{C}$ with relative humidity of $75 \%$ for a period of four 
and eight days. Then, the inflorescences were cut at $2 \mathrm{~cm}$ from the stalk base and immediately placed in the vases with distilled water at room temperature of $25^{\circ} \mathrm{C}$. At every $48 \mathrm{~h}$, the vase water was replaced and the base of the stalk was re-cut at $2 \mathrm{~cm}$ to avoid clotting. The vase life was determined as the number of days between the removal of the inflorescences from the cold storage and until had at least $50 \%$ of abscised flowers and wilted petals (Moraes et al. 2007). At frequency of $24 \mathrm{~h}$, the changes in fresh mass, abscission of flowers and rates of water uptake and transpiration were determined.

The changes of inflorescences fresh mass were evaluated by the increase or reduction of mass compared to the weight from the beginning of the vase life (100\%) after four or eight days of cold storage. The daily rate of abscised flowers followed the procedure established by Finger et al. (2008). The rate of water uptake and transpiration by the inflorescences were determined using the method described by Van Doorn et al. (2002) as follows. Individual inflorescences were weighed and the base was placed in individual vials containing $50 \mathrm{~g}$ of distilled water at $20^{\circ} \mathrm{C}$. At every $24 \mathrm{~h}$, the vials were weighed again with and without the inflorescences. In order to eliminate the water evaporation from the vials, the top was wrapped with four layers polyvinyl chloride plastic film. The rate of water uptake was obtained by its consumed mass in $\mathrm{mg} \mathrm{day}^{-1}$ as follow:

$$
\mathrm{MW}=\left(\mathrm{MW}_{\mathrm{i}}-\mathrm{MW}_{\mathrm{f}}\right)
$$

where MW was mass of uptake water from the vial; $\mathrm{MW}_{\mathrm{f}}$ final weight of water after $24 \mathrm{~h}$, and $\mathrm{MW}_{\mathrm{i}}$ as initial weight of water.

Transpiration rate in each inflorescence was estimated in $\mathrm{mg} \mathrm{day}^{-1}$ using the following formula:

$$
\mathrm{TR}=\left(\mathrm{FM}_{\mathrm{i}}+\mathrm{MW}\right)-\mathrm{FM}_{\mathrm{f}}
$$

where TR was transpiration rate per inflorescence; $\mathrm{FM}_{\mathrm{f}}$ the final fresh mass of the inflorescence after hydration; $\mathrm{FM}_{\mathrm{i}}$ as the initial fresh mass of the inflorescence before hydration; MW as the mass of uptake water. The ratio of transpiration/water uptake was estimated by dividing the TR/MW.

A completely randomized design was used with a factorial $2 \times 2 \times 2$ (treated with STS and control $\times$ two storage temperatures $\times 2$ periods of storage) with four replicates composed by four inflorescences each. For the water uptake and transpiration determination 16 individual inflorescences were used. The data were submitted to analysis of variance (ANOVA) and comparison of means was carried out using the Scott-Knott test $(P>0.05)$. Standard error was used for descriptive statistics.

\section{RESULTS AND DISCUSSION}

Regardless of the pulsing with $2.0 \mathrm{mM}$ STS for 30 minutes, there was an increase in the inflorescence total fresh mass when placed in the water, following the storage for four or eight days at 5 or $10^{\circ} \mathrm{C}$ (Fig. 2A and 2B). However, the higher increase in the mass was obtained for those inflorescences treated with the STS, enhancing the fresh mass in 5.8 and $13 \%$ for the stalks stored at $10^{\circ} \mathrm{C}$ for four or eight days, respectively. Afterwards, the fresh mass decreased, even after re-cutting the base of the stalk at every two days (Fig. 2A and 2B).

Independent of STS pulsing, the dry storage of the inflorescences at $5^{\circ} \mathrm{C}$ for eight days induced bigger rates of fresh mass loss throughout the subsequent vase life (Fig. 2A and 2B). Similar to this work, Mengüç and Zencirkiran (1996) found that the highest rates of fresh mass loss during the vase life of Alstromeria were related to longer periods of cold storage.

The inflorescences pulsed with $2.0 \mathrm{mM}$ STS before the storage at $10^{\circ} \mathrm{C}$ had the highest increase of fresh mass within the first $24 \mathrm{~h}$ in the vase, regardless if the flowers were stored for four or eight days (Fig. 2A and 2B). Afterwards, there was a continuous decrease in the stalk fresh mass for all the treatments, even after the base of the stalks was re-cut at every two days. Particularly in inflorescences stored for eight days, the new cut done at the base of the stem did not have any noticeable effect on the rate of fresh mass loss, probably by having no significant influence on the water uptake by the stem or due to a high transpiration rate experience by the inflorescence. Van Doorn et al. (1995) found that the petal wilting in cut Iris flowers was due higher rate of transpiration compared to water uptake. 


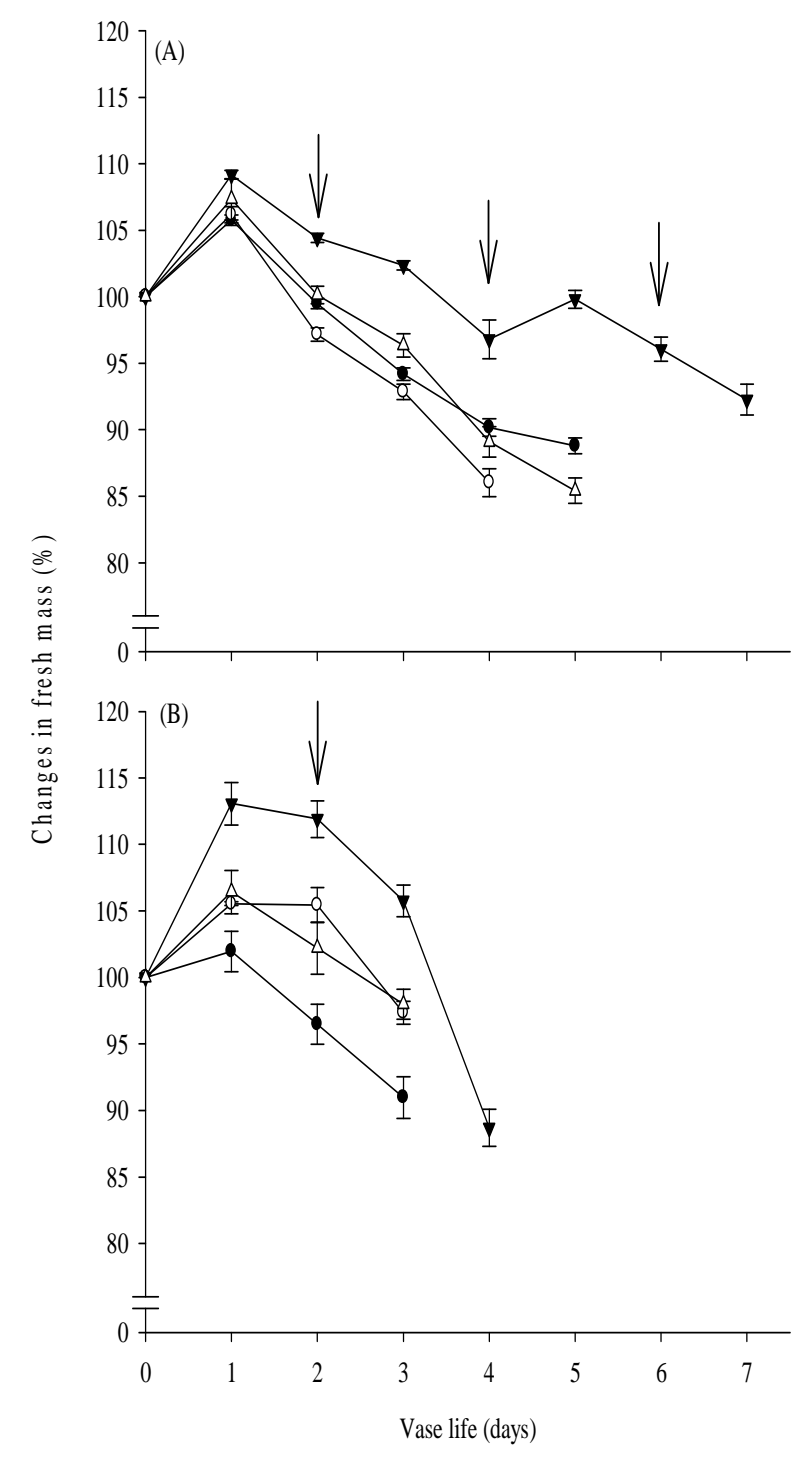

Figure 2 - Changes in fresh mass of E. ibaguense inflorescences during vase life previously pulsed with $2 \mathrm{mM} \mathrm{STS}$ and stored for $4(\mathrm{~A})$ and $8(\mathrm{~B})$ days at $5\left(-{ }^{-}\right)$and $10^{\circ} \mathrm{C}\left(-\nabla^{-}\right)$, and control at $5\left(-\mathrm{O}^{-}\right)$and $10^{\circ} \mathrm{C}\left(-\triangle^{-}\right)$. The arrows indicate the re-cut of the stem base. Mean \pm SE, $n=16$.

Once the cold storage of four or eight days was over and the length of vase life was initiated, the control flowers had higher rates of flower abscission compared to the $2.0 \mathrm{mM}$ STS pulsed stalks, regardless of the temperature or length of storage (Fig. 3A and 3B). Inhibition of flower abscission was achieved by pulsing the $E$. ibaguense inflorescences with STS or by fumigating with 1-MCP immediately after the harvest, followed by keeping the flowers in vase containing only water (Finger et al. 2008). These results showed that the pulsing with STS done four or eight days before being placed in the vase with water was still efficient in reducing the flowers abscission compared to the untreated stalks (Fig. $3 \mathrm{~A}$ and $3 \mathrm{~B})$. For the control stalks, stored for four days, the accentuated rate of abscission started one and two days after the removal from the cold storage at 5 and $10^{\circ} \mathrm{C}$, respectively. But, for the STS treated stalks, the sharp increase in abscission was delayed and began at day three and four for the temperatures of 5 and $10^{\circ} \mathrm{C}$, respectively (Fig. 
$3 \mathrm{~A}$ and $3 \mathrm{~B})$. Regardless of the temperature of storage, in the flowers with eight days storage, the efficiency of the STS treatment was much lower, with high drop of flower within the first day of vase life. This result might be related to the presence of chilling injury symptoms due to the prolonged cold storage, as previously observed in bird-of-paradise flowers during a long term cold storage at 5 and $10^{\circ} \mathrm{C}$ (Finger et al. 2003).

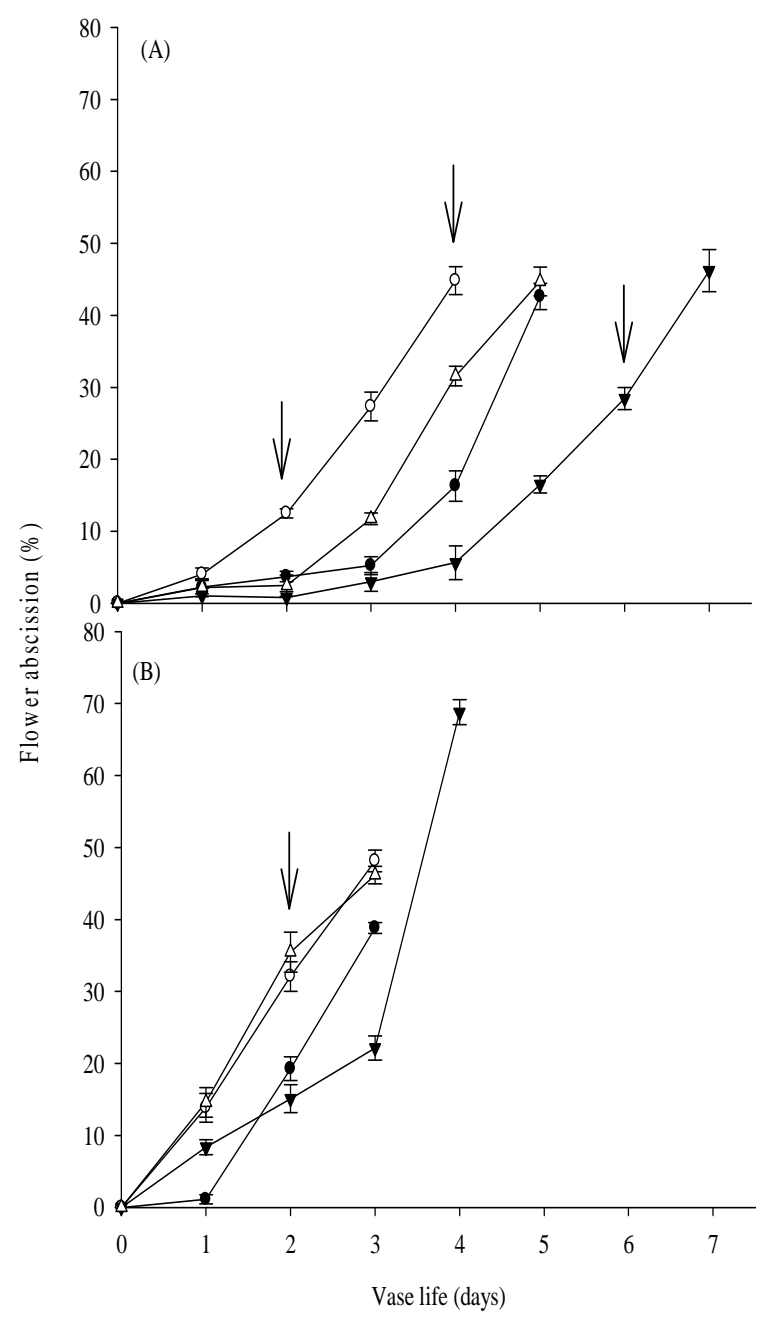

Figure 3 - Abscission of E. ibaguense flowers during vase life previously pulsed with 2 mM STS and stored for 4 (A) and 8 (B) days at $5(--)$ and $10^{\circ} \mathrm{C}(-\nabla-)$, and control at 5 $\left(-\mathrm{O}^{-}\right)$and $10^{\circ} \mathrm{C}(-\triangle-)$. The arrows indicate the re-cut of the stem base. Mean $\pm \mathrm{SE}, n$ $=16$.

The vase life was longer for those inflorescences pulsed with $2.0 \mathrm{mM}$ STS, independently if they were stored for four or eight days in cold storage (Fig. 4A and 4B). The longest vase life, 6.5 days, was obtained for the inflorescences treated with STS and stored for four days at $10^{\circ} \mathrm{C}$, and the shortest life of 2.2 days for the inflorescences stored without pulsing with STS for eight days at $5^{\circ} \mathrm{C}$ (Fig. 4A and 4B). However, the vase life was improved in one day when the inflorescences were treated with STS, which was able to alleviate the chilling injury especially in those inflorescences stored at $5^{\circ} \mathrm{C}$.

The symptoms of chilling in these flowers included the development of wilting and necrotic spots on the petals, which might appear only after moving the inflorescences from the cold storage to room temperature (Fig. 5). Several important commercial flowers are chilling sensitive, including heliconias, ginger, Alpinea and bird-ofparadise (Finger and Barbosa 2006). 


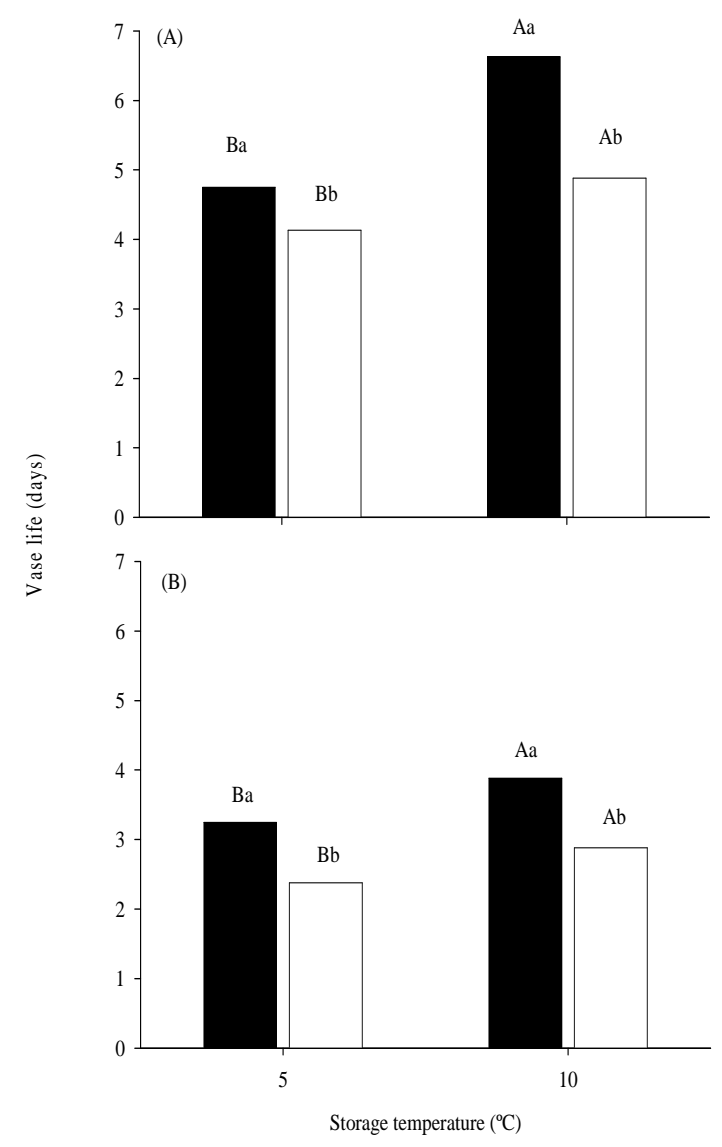

Figure 4 - Vase life of E. ibaguense flowers previously pulsed with $2 \mathrm{mM}$ STS (black bars) and stored for 4 (A) and 8 (B) days and control (white bars) at 5 and $10^{\circ} \mathrm{C}$. Means followed by different upper case letters are significantly different between temperatures at same treatment and the lower case letters between the $2 \mathrm{mM}$ STS pulsed and control inflorescences at the same temperature by Scott-Knott test at 5\% probability, $n=16$.

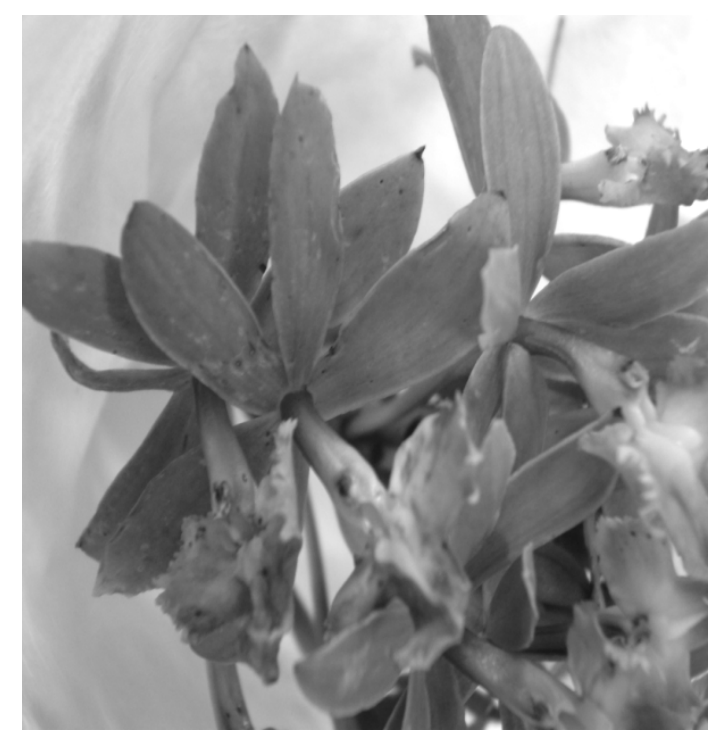

Figure 5 - Development of chilling symptoms of necrosis spots in E. ibaguense inflorescences stored for 8 days at $5^{\circ} \mathrm{C}$. 
Independent of $2 \mathrm{mM}$ STS pulsing, the inflorescences stored for four days had better water balance throughout the vase life compared to eight days storage, because the ratio transpiration/water uptake (TR/MW) had a less sharp increase after removed from the cold storage and placed in the water (Fig. 6A and 6B). During the first day of vase life, all the treatments had a higher rate of water uptake, because the ratio TR/MW was below 1.0, afterwards started to increase with different rates depending on the treatment (Fig. 6A and 6B).

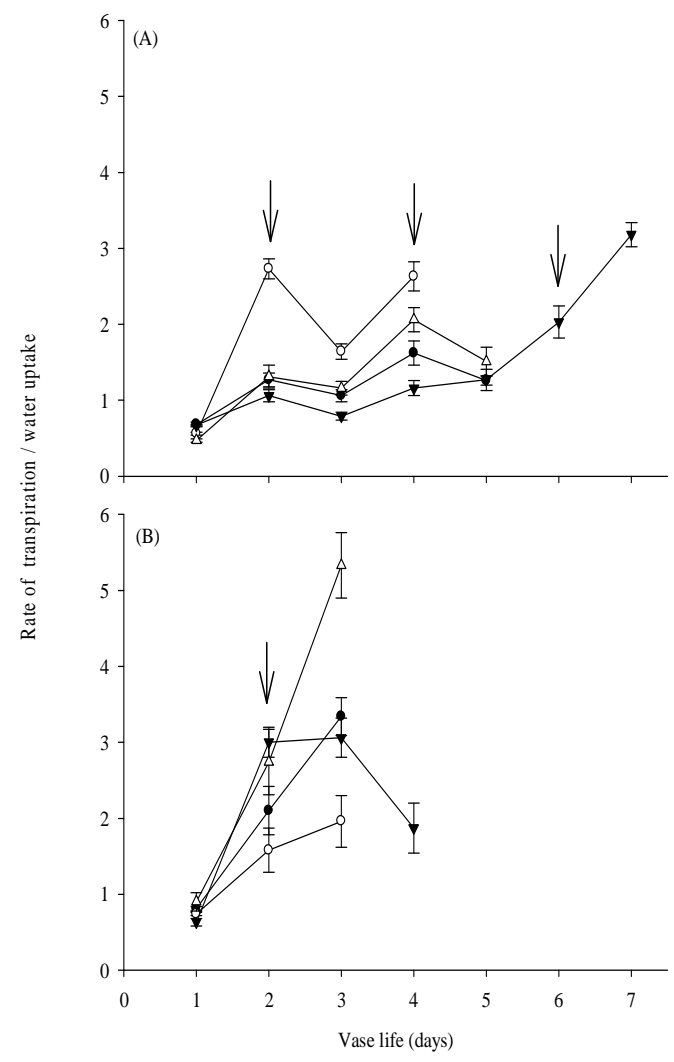

Figure 6 - Ratio transpiration/water uptake of E. ibaguense flowers during vase life previously pulsed with $2 \mathrm{mM}$ STS and stored for 4 (A) and 8 (B) days at $5(--)$ and $10^{\circ} \mathrm{C}$ $(-\boldsymbol{\nabla}-)$, and control at $5\left(-\mathrm{O}^{-}\right)$and $10^{\circ} \mathrm{C}\left(-\triangle^{-}\right)$. The arrows indicate the recut of the stem base. Mean \pm SE, $n=16$.

In the cut anthurium, Sankat and Mujaffar (1994) found that when the ratio TR/MW was above 1.5 symptoms of water stress were evident. This seemed to be true for the E. ibaguense inflorescences, since the control treatments stored for four days at $5^{\circ} \mathrm{C}$ and eight days at $10^{\circ} \mathrm{C}$ had the sharpest increase in the ratio TR/MW well above 1.5 , which resulted in a four and three day vase live (Fig. 6A and 6B). The lowest rate of increase in the ratio $\mathrm{TR} / \mathrm{MW}$ was present in the inflorescences treated with STS and stored for four days at $10^{\circ} \mathrm{C}$, which was above 1.5 after six days in the vase, resulting in the longest vase life compared to all the treatments (Fig. 4A). Re- cuting the base of the stem at every two days had some effect in temporarily restoring the water balance in the inflorescences stored for four days. The re-cut was particular affective in the control inflorescences stored for four days at $5^{\circ} \mathrm{C}$, lowering the ratio $\mathrm{TR} / \mathrm{MW}$ from 2.8 to 1.8 between the second and third day of vase life, but still was above the 1.5 critical value (Fig. 6A).

The STS treatment was affective in keeping the ratio $\mathrm{TR} / \mathrm{MW}$, especially in the flowers stored for four days, which indicated that ethylene might be involved in the obstruction of the xylem vases, impairing the water balance. 


\section{ACKNOWLEDGMENTS}

The authors thank to FAPEMIG for the financial support and to CAPES for the concession of a scholarship to Joice Simone dos Santos.

\section{REFERENCES}

Finger FL, Moraes JP, Barbosa JG, Grossi JAS. Vase life of bird-of-paradise flowers influenced by pulsing and term of cold storage. Acta Hortic. 2003; 625: 863-867.

Finger FL and Barbosa JG. Postharvest physiology of cut flowers. In: Advances in Postharvest Technologies for Horticultural Crops, ed. B. Noureddine and S. Norio, S. Research Signpost, Kerala, 2006; 373-393.

Finger FL, Moraes PJ, Mapeli AM, Barbosa JG, Cecon PR. Longevity of Epidendrum ibaguense flowers as affected by pre-loading treatments and vase solution. J Hortic Sci \& Biotech. 2008; 83: 144-147.

Jaroenkit T, Paull RE. Postharvest handling of heliconia, red ginger and bird-of-paradise. Hort Technology. 2003;13:259-266.

Mapeli AM, Oliveira LS, Megguer CA, Barbosa JG, Barros RS, Finger FL. Characterisation of respiration, ethylene production, and carbohydrate contents during flower opening in Epidendrum ibaguense. $J$ Hortic Sci \& Biotech. 2009; 84: 609-612.

Mengüç A, Zencirkiran M. A research on cold storage of Alstromeria cv. 'Ostara' cut flowers. Acta Hortic. 1996; 429: 591-596.
Moraes PJ, Finger FL, Barbosa JG, Cecon PR, Longevidade pós-colheita da orquidea Epidendrum ibaguense Kunth. Rev Bras Hortic Ornamen. 2007; 13: 31-37.

Moraes PJ, Finger FL, Mapeli AM, Cecon PR, Barbosa JG. Growth and flower development of Epidendrum ibaguense orchid. Acta Hortic. 2009; 813: 565-570.

Morris LL. Chilling injury of horticultural crops: an overview. HortScience. 1982; 17, 157-158.

Pridgeon A. The illustrated encyclopedia of orchids. Timber Press, Portland; 2003.

Sankat CK, Mujaffar S. Water balance in cut anthurium flowers in storage and its effect on quality. Acta Hortic. 1994; 2: 723-732.

Suzuki A, Leonard RT, Nell TA, Barrett JE, Clark DG. Effects of retail hydration on water uptake and quality of "Madame Delbard" roses after long term transport. Acta Hortic. 2001; 543: 251-256.

Verlinden S, Boatright J, Woodson WR. Changes in ethylene responsiveness of senescence-related genes during carnation flower development. Physiol Plantarum. 2002; 116: 503-511.

Van Doorn WG, Abadie P, Belde PJM. Alkylethoxylate surfactants for rehydration of roses and Bouvardia flowers. Postharvest Biol Technol. 2002; 24: 327333.

Van Doorn WG, Harkema H, Song JS. Water relations and senescence of cut Iris flowers: effects of cycloheximide. Postharvest Biol Technol. 1995; 5: 345-351.

Van Doorn WG, Water relations of cut flowers. Hortic Reviews. 1997; 18: 1-85. 